\title{
Correction to: One Step is Enough
}

\section{David Ripley ${ }^{1}$}

Published online: 20 December 2021

(C) Springer Nature B.V. 2021

\section{Erratum to: J Philos Logic https://doi.org/10.1007/s10992-021-09615-7}

In this article, references 63 to 71 and their citations should have been (please see below):

63. Cobreros, P., Égré, P., Ripley, D., \& van Rooij, R. (2012). Tolerant, classical, strict. Journal of Philosophical Logic, 41(2), 347-385.

64. Ripley, D. (2012). Conservatively extending classical logic with transparent truth. Review of Symbolic Logic, 5(2), 354-378.

65. Ripley, D. (2013). Revising up: strengthening classical logic in the face of paradox. Philosophers' Imprint, 13(5), 1-13.

66. Ripley, D. (2013). Sorting out the sorites. In K. Tanaka, F. Berto, E. Mares, \& F. Paoli (Eds.) Paraconsistency: logic and applications (pp. 329-348). Dordrecht: Springer.

67. Cobreros, P., Égré, P., Ripley, D., \& van Rooij, R. (2013). Reaching transparent truth. Mind, 122(488), 841-866.

68. Ripley, D. (2015). Comparing substructural theories of truth. Ergo, 2(13), 299-328. 69. French, R. \& Ripley, D. (2019). Two traditions in abstract model theory. Synthese. To appear.

70. French, R. \& Ripley, D. (2019). Valuations: bi, tri, and tetra. Studia Logica, 107(6), 1313-1346.

The original article has been corrected.

Publisher's Note Springer Nature remains neutral with regard to jurisdictional claims in published maps and institutional affiliations.

The online version of the original article can be found at https://doi.org/10.1007/s10992-021-09615-7

David Ripley

davewripley@gmail.com

1 Philosophy Department SOPHIS Building 11, Monash University, Clayton, VIC 3800, Australia 